\title{
ARTICLE
}

\section{Private Processes and Public Values: Disciplining Trade in Forest and Ecosystem Risk Commodities via Non-Financial Due Diligence}

\section{Enrico Partiti* (1)}

First published online 29 July 2021

\begin{abstract}
This article takes stock of the many private and public instruments enacted transnationally to tackle the pressing problem of deforestation, ecosystem conversion, and associated human rights violations caused by international demand for and trade in agricultural commodities. The article argues that non-financial due diligence based on no-conversion criteria, and in line with the United Nations Guiding Principles on Business and Human Rights, holds considerable potential for ensuring deforestation-free value chains by enrolling and scaling up firm-level supply-chain management systems and private standards. The article introduces the main features of a possible European Union measure that disciplines via non-financial due diligence the placing on the market of commodities and products associated with deforestation, ecosystem conversion, degradation of forests and ecosystems, and associated human rights violations. Such a measure would also have the effect of streamlining initiatives enacted by private authority.
\end{abstract}

Keywords: Due diligence, Deforestation, Private regulation, Transnational governance, Voluntary standards and pledges

\section{INTRODUCTION}

Various private initiatives have emerged to tackle deforestation and ecosystem conversion fuelled by trade in agricultural commodities. This article aims to study the alignment of private action with public interests and the influence that public authority can exert over transnational private regulation, ${ }^{1}$ in particular, on the issue of

* Tilburg University, Law School, Tilburg (The Netherlands) and T.M.C. Asser Institute, The Hague (The Netherlands).

Email: e.d.partiti@tilburguniversity.edu.

This contribution was written in the context of research undertaken for Greenpeace as well as a research project that received funding from the European Research Council (ERC) under the European Union's Horizon 2020 research and innovation programme (Grant Agreement No. 725798).

1 K.W. Abbott \& D. Snidal, 'Strengthening International Regulation through Transnational New Governance: Overcoming the Orchestration Deficit' (2009) 42(2) Vanderbilt Journal of Transnational 
sustainability. ${ }^{2}$ It thus contributes to transnational legal scholarship on the interplay and potential regulatory complementarity between public and private regimes. ${ }^{3}$ As it consists of several intersecting, misaligned and even conflicting regimes, the incipient transnational legal order $(\mathrm{TLO})^{4}$ for trade and deforestation is a fitting case study to appraise the steering potential of the former through enrolling and leveraging strategies. The article explores how public authority can intervene in aligning and consolidating an otherwise conflicting TLO - which consists of various public and, notably, private components - to discipline deforestation, conversion, degradation, and associated human rights violations.

In line with European Union (EU) policy priorities, ${ }^{5}$ the article suggests a legal avenue to improve EU action on deforestation through the mobilization of private authority. An EU feasibility study indicated that non-financial due diligence would be the regulatory tool with the highest degree of effectiveness in achieving deforestation-free value chains. ${ }^{6}$ The contribution analyzes how a possible EU measure building upon the EU Timber Regulation (EUTR $)^{7}$ may align and step up firms' supply-chain management systems and voluntary private standards in a nascent TLO. A possible EU measure disciplining trade in certain agricultural commodities would contribute to the protection of forests, natural ecosystems, and land-related human rights by requiring that, regardless of their origin, only products and commodities that are neither associated with forest and ecosystem conversion and degradation nor with associated human rights violations can be placed on the EU market. This obligation of result would be operationalized by an obligation of conduct, namely, to perform non-financial due diligence. In addition to its potential effectiveness, the alignment of non-financial due diligence with the human rights due diligence (HRDD) framework is the keystone for enrolling and directly improving supply-chain management activities of firms marketing agricultural commodities in the EU, as well as for harmonizing private standards. While this contribution focuses on the EU, the regulatory model is extendable to other jurisdictions. In the United States, for example,

Law, pp. 501-78, at 510; K.W. Abbott, D. Levi-Faur \& D Snidal, 'Theorising Regulatory Intermediaries: The RIT Model' (2017) 660 Annals of the American Academy of Political and Social Science, pp. 14-31.

2 E. Partiti, 'Orchestration as a Form of Public Action: The EU Engagement with Voluntary Sustainability Standards' (2019) 25(1) European Law Journal, pp. 94-117; S. Wood et al. (eds), Transnational Business Governance Interactions: Advancing Marginalised Actors and Enhancing Regulatory Quality (Edward Elgar, 2019).

3 F. Cafaggi, 'New Foundations of Transnational Private Regulation' (2011) 38(1) Journal of Law and Society, pp. 20-49.

4 T. Halliday \& G. Shaffer, 'Transnational Legal Orders', in T. Halliday \& G. Shaffer (eds), Transnational Legal Orders (Cambridge University Press, 2015), pp. 3-72.

5 European Commission Communication, 'Stepping up EU Action to Protect and Restore the World's Forests', 23 July 2019, COM(2019) 352 final; European Commission Communication, 'The European Green Deal', 11 Dec. 2019, COM(2019) 640 final.

6 Ecofys, Milieu \& COWI, 'Feasibility Study on Options to Step Up EU Action against Deforestation', Final Report, Jan. 2018, pp. 88-9, available at: https://ec.europa.eu/environment/forests/pdf/feasibility_ study_deforestation_kh0418199enn_main_report.pdf.

7 Regulation (EU) No. 995/2010 Laying Down the Obligations of Operators who Place Timber and Timber Products on the Market [2010] OJ L 295/13 (EUTR). 
certain senators have signalled their intention to regulate market access for products associated with deforestation. ${ }^{8}$

This contribution is structured as follows. Section 2 briefly illustrates how deforestation, ecosystem conversions, and human rights violations are driven by agricultural expansion and trade. Section 3 sketches a theoretical framework that links literature on transnational legal ordering and transnational business-governance interactions to identify a role for public authority vis-à-vis transnational private initiatives, and the enrolling mechanisms through which it unfolds. Section 4 assesses key elements of the transnational regulatory governance of deforestation, focusing on supply-chain management, private regulatory initiatives, and their substantive requirements. The objective is to discuss the current configuration of private regimes and to highlight shortcomings and coordination challenges which public authority will remedy. Section 5 discusses how EU intervention affects the establishment of a TLO disciplining trade in certain agricultural commodities. It addresses due diligence obligations in the context of the EUTR, the normative desirability of the HRDD framework, its extension to conversion-related domains, and the impact of non-financial due diligence on private standards. Section 6 concludes.

\section{ECONOMIC DRIVERS OF DEFORESTATION}

Between 2010 and 2015, 7.6 million hectares of forests were lost every year. ${ }^{9}$ Deforestation not only causes immense biodiversity loss; it is also the second largest source of greenhouse gas (GHG) emissions, ${ }^{10}$ accounting for $12 \%$ to $29 \%$ of total emissions over the last two decades. ${ }^{11}$ Agricultural production is a major driver of deforestation. Fifty-one per cent of global tree cover loss between 2000 and 2015 was caused by agricultural production, including pasture, and another $26 \%$ was a a result of forestry activities. ${ }^{12}$ Forests and other natural ecosystems also suffer from degradation through loss of or reduction in ecosystem services provided; 850 million hectares of tropical forest and forest land were in a degraded state in $2002 .{ }^{13}$ Extraction of timber is the leading cause of forest degradation.

A large proportion of forest clearance occurs in breach of local legal requirements. However, between 2000 and 2012 only half of the total tropical deforestation was

8 B. Schatz \& M.B. Jenkins, 'Deforestation Can't Be Stopped by Voluntary Action Alone', World Economic Forum, 15 Jan. 2020, available at: https:/www.weforum.org/agenda/2020/01/deforestation-voluntaryaction-regulation.

9 Food and Agriculture Organization of the United Nations (FAO), 'Global Forest Resources Assessment 2015', p. 3, available at: http://www.fao.org/forest-resources-assessment/past-assessments/fra-2015/en.

10 P. Smith et al., 'Agriculture, Forestry and Other Land Use (AFOLU)', in Intergovernmental Panel on Climate Change (O. Edenhofer et al. (eds)), Climate Change 2014: Mitigation of Climate Change. Contribution of Working Group III to the Fifth Assessment Report of the Intergovernmental Panel on Climate Change (Cambridge University Press, 2014), pp. 811-922.

11 G. van der Werf et al., 'CO 2 Emissions from Forest Loss' (2009) 2(11) Nature Geoscience, pp. 737-8.

12 P.G. Curtis et al., 'Classifying Drivers of Global Forest Loss' (2018) 361(6407) Science, pp. 1108-11.

13 FAO, n. 9 above, p. 22. 
caused by illegal conversion. ${ }^{14}$ Where political leaders relax law enforcement and conservation activities to favour agribusiness, it becomes difficult to consider the legality of production or land conversion as a meaningful notion in the global fight against deforestation. To tackle forest conversion and degradation, addressing illegal conversion is therefore not enough. ${ }^{15}$ Furthermore, protecting only forests generates leakage, as it risks displacing conversion to non-forest ecosystems. The decoupling of deforestation and soy production in the Amazon, while successful, displaced soy expansion to the Cerrado, with consequent extensive conversion of tropical savannah. ${ }^{16}$ Finally, human rights violations - in particular, land use and the cultural rights of Indigenous communities, together with the absence of free, prior and informed consent (FPIC) - are often associated with forest and ecosystem conversion. Social and environmental considerations are inextricably intertwined, and can be addressed holistically only by taking into account both environmental and human rights impacts.

The concept of forest-risk commodities indicates agricultural commodities associated with deforestation. ${ }^{17}$ However, the term 'forest and ecosystem-risk commodities' (FERCs) is proposed here as it recognizes that many ecosystems other than forests are affected by agricultural expansion. FERCs include soy, beef, and palm oil which, alone, are responsible for $80 \%$ of tropical deforestation. ${ }^{18}$ International trade worsens the negative social and environmental impacts of FERCs given that a considerable share of their production is exported. The EU is a major global importer. In 2014, EU demand was responsible for $41 \%$ of global imports of beef, $25 \%$ of palm oil, $15 \%$ of soy, as well as large shares of FERCs such as maize $(30 \%)$, cocoa $(80 \%)$, coffee $(60 \%)$, and rubber $(25 \%) .{ }^{19}$

In spite of global concerns about climate change, especially in connection with deforestation and international trade, effective multilateral agreements on the protection of forests and other ecosystems continue to be lacking. ${ }^{20}$ Even where unilateral

14 S. Lawson et al., 'Consumer Goods and Deforestation: An Analysis of the Extent and Nature of Illegality in Forest Conversion for Agriculture and Timber Plantation', Forest Trends Report Series, Sept. 2014, available at: https:/www.forest-trends.org/wp-content/uploads/imported/for168-consumer-goods-anddeforestation-letter-14-0916-hr-no-crops_web-pdf.pdf.

15 United Nations (UN) New York Declaration on Forests, New York, NY (US), 23 Sept. 2014, available at: https://www.undp.org/content/dam/undp/library/Environment \%20and\%20Energy/Forests/New\%20York \%20Declaration\%20on\%20Forests_DAA.pdf; see also: https://forestdeclaration.org.

16 E.Y. Arima et al., 'Statistical Confirmation of Indirect Land Use Change in the Brazilian Amazon' (2011) 6(2) Environmental Research Letters online article 024010, available at: https:/iopscience.iop.org/article/10.1088/1748-9326/6/2/024010/pdf.

17 M. Rautner, M. Leggett \& F. Davis, The Little Book of Big Deforestation Drivers (Global Canopy Programme, 2013), p. 17.

18 Global Environment Facility (GEF), Taking Tropical Deforestation out of Commodity Supply Chains (GEF, 2015), available at: https:/www.thegef.org/sites/default/files/publications/GEF_CommoditiesR3_0.pdf.

19 Ecofys, Milieu \& COWI, n. 6 above, pp. $48 \mathrm{ff}$.

20 The 1992 Rio Declaration on Forests is non-binding and the 2006 International Tropical Timber Agreement is concerned with expansion of international trade in tropical timber, and enhancing sustainable forest management cooperation: UN Conference on Environment and Development, 'Agenda 21, Rio Declaration, Forest Principles', Rio de Janeiro (Brazil), 14 June 1992, UN Doc. A/CONF.151/26 (vol. I), available at: https://www.un.org/esa/dsd/agenda21/Agenda\%2021.pdf; International Tropical 
intervention could be normatively and legally justifiable, ${ }^{21}$ states remain confronted with jurisdictional limitations. These notwithstanding, private authority contributes to bringing degrees of legalization across global value chains. ${ }^{22}$ As is typical for questions of environmental law, ${ }^{23}$ the impact of agriculture on deforestation is governed by a multi-level and multi-actor patchwork of instruments that blur the boundaries between the public and the private, and between pursuing economic and non-economic goals. These tools include voluntary supply-chain sourcing commitments enacted by commodity traders, voluntary sustainability standards addressing a single commodity or a specific use (such as biofuel production), no-deforestation pledges monitored and enforced by multi-stakeholder coalitions, and public measures that require legality of production via due diligence. However, for reasons that will be explained in this article, such private regulatory initiatives have limited effectiveness. There is therefore an urgent need for public intervention.

\section{A ROLE FOR PUBLIC AUTHORITY IN THE TRANSNATIONAL REGULATION OF DEFORESTATION}

The notion of the TLO identifies a collection of formalized legal norms, organizations and actors that authoritatively discipline the understanding and practice of law across national jurisdictions in a given domain or around a specific problem. ${ }^{24}$ Transnational legal ordering is characterized by its procedural nature. ${ }^{25}$ Over time, top-down and bottom-up interactions between layers of public and private rules generate reciprocal incremental adjustments of norms and align them, more or less effectively, with the issue area in question. This may lead to institutionalization, which is the effective orientation of social expectation, communication and action that occurs where practices converge, diffuse, and are taken for granted. ${ }^{26}$ A TLO may apply only to part of the issue considered, and may overlap with competing regimes underpinned by other, possibly less stringent, rules. ${ }^{27}$ While institutionalization is a sociological phenomenon, this article appraises the first essential steps towards that goal - namely, the formation of a normatively coherent, definitionally clear and predictable, and potentially effective $\mathrm{TLO}^{28}$ addressing forest and ecosystem conversion regardless of its legality in countries

Timber Agreement, Yokohama (Japan), 27 Jan. 2006, in force 7 Dec. 2011, available at: https://treaties. un.org/pages/ViewDetails.aspx?src=TREATY\&mtdsg_no=XIX-46\&chapter=19\&clang=_en.

21 Transnational Environmental Law, pp. 31-41.

22 A.C. Cutler, Private Power and Global Authority: Transnational Merchant Law in the Global Political Economy (Cambridge University Press, 2003).

23 R.O. Keohane \& D.G. Victor, 'The Regime Complex for Climate Change (2011) 9(1) Perspectives on Politics, pp. 7-23.

24 Halliday \& Shaffer, n. 4 above, p. 11.

25 H.H. Koh, 'Transnational Legal Process' (1996) 75 Nebraska Law Review, pp. 181-207.

26 J.C March \& J.P. Olsen, 'The Institutional Dynamics of International Political Orders' (1998) 52(4) International Organisation, pp. 942-69.

27 Halliday \& Shaffer, n. 4 above, p. 49.

28 I.e., the meaning of the law is stabilized and ambiguity is reduced: Halliday \& Shaffer, n. 4 above, p. 43. 
of production, and associated human rights violations. Such a TLO would entail various components of public and private authority as well as mandatory elements to ensure that compliance is not just symbolic.

This contribution is particularly interested in the role of public authority in steering the formation of such a TLO, and in establishing and reinforcing its substantive and procedural coordinates. Public authority at the national and regional levels remains central to rulemaking, rule recognition and rule enforcement as TLOs are intimately connected with public lawmaking. ${ }^{29}$ Unilateral legal developments in a jurisdiction with large economic power may also affect private behaviour in others. ${ }^{30}$ This holds particularly true for private standardization bodies and firms' management systems. Transnational private regulatory initiatives are based on existing international and national rules, and are exposed to various pressures from public authority. ${ }^{31}$ Public action has been, and remains, instrumental in the emergence, implementation, enforcement, and evolution of transnational sustainability governance. ${ }^{32}$ TLO processes also affect public authority. ${ }^{33}$ When interacting with private authority, this phenomenon takes the form of a hybridization of regulatory forms, where public regulation absorbs features of private regimes, and vice versa. ${ }^{34}$ Private regulation is thus a 'laboratory' of standards and benchmarks to be later institutionalized through public regulation. ${ }^{35}$

While the notion of the TLO does not prescribe desirable conduct on the part of public authority, scholarship on transnational business governance interactions (TBGI) casts some light on the interactions between public and private authority that characterize a TLO. TBGI literature also offers normative guidance to identify circumstances where interactions between regimes can be harnessed to improve output and outcomes of transnational regulation. ${ }^{36}$ TBGI scholarship starts from the premise that public regulators are increasingly in interplay with other regulatory actors. ${ }^{37}$ Normatively, public authority retains a distinct function in scaling up private regimes. It can coordinate between various regimes and actors, and operate as an additional and complementary locus of rulemaking authority to remedy the shortcomings of private governance. ${ }^{38}$

29 Halliday \& Shaffer, n. 4 above, p. 13.

30 Shaffer \& Bodansky, n. 21 above, p. 32.

31 T. Bartley, 'Transnational Governance as the Layering of Rules: Intersection of Public and Private Standards' (2011) 12(2) Theoretical Inquiries in Law, pp. 517-42.

32 S. Ponte, Business Power and Sustainability in a World of Global Value Chains (Zed Books, 2019), pp. $175-225$.

33 Halliday \& Shaffer, n. 4 above, p. 13.

34 Cafaggi, n. 3 above.

35 C.F. Sabel \& J. Zeitlin, 'Learning from Difference: The New Architecture of Experimentalist Governance in the EU' (2008) 14(3) European Law Journal, pp. 271-327.

36 S. Wood et al., 'Transnational Business Governance Interactions, Regulatory Quality and Marginalized Actors: An Introduction', in Wood et al., n. 2 above, pp. 1-26.

37 M.L. Djelic \& K. Sahlin-Andersson, 'Institutional Dynamics in a Re-ordering World', in M.L. Djelic \& K. Sahlin-Andersson (eds), Transnational Governance: Institutional Dynamics of Regulation (Cambridge University Press, 2006), pp. 375-97.

38 Discussing various strands of literature: J. Grabs, G. Auld \& B. Cashore, 'Private Regulation, Public Policy, and the Perils of Adverse Ontological Selection (2021) Regulation \& Governance (forthcoming), pp. 1-26, at 11, available at: https://onlinelibrary.wiley.com/doi/full/10.1111/rego.12354. 
The focus here is on deliberate, cooperative interactions between public and private authority with the aim of engaging private rulemakers and regulatory addressees (firms), and in particular on the standards they draft and their implementation. These interactions can be leveraged to affect the regulatory institutions, the nature and the content of their rules, and the overall conduct of regulated entities. ${ }^{39}$

While public-private interactions take many forms, including those of an informal nature, this article is concerned particularly with interactions unfolding through legal instruments and obligations that directly or indirectly impact on private authority. Such interactions can be directed to increase the ambition and scope of private norms and make them more effective and responsive, while fostering accountability and participation. ${ }^{40}$ Where such interactions include public and private actors at the national and transnational levels they may enhance the regulatory capacity and legitimacy of both public and private regulatory regimes. ${ }^{41}$ Private authority offers institutional complementarity to public action. ${ }^{42}$ Private regimes operating across jurisdictions offer implementing and monitoring functions to provisions and principles determined in public instruments, especially where public authority lacks the capacity or will to define rules in technical or controversial domains, or does not have the authority to monitor compliance. ${ }^{43}$ At the same time, transnational private regulators possess incomplete forms of authority, and must cooperate with public authority to compensate for their capacity, authority, and legitimacy deficits. ${ }^{44}$ Interactions thus foster a division of labour and of regulatory competences, resulting in improved overall effectiveness and legitimacy.

Among possible mechanisms for interaction, enrolment and leveraging are here considered in the light of their potential to enhance the regulatory capacity of public and private regimes and thus of the overarching TLO. ${ }^{45}$ Interactions that were successfully harnessed to enhance regulatory quality or advance the interests of marginalized actors include the enrolment and leveraging of third parties and the strategic mobilization of their resources and capabilities. ${ }^{46}$ Through enrolment, a process of coercive isomorphism leads to scaling up private regimes according to criteria established by public authority. ${ }^{47}$ The success of public authorities' enrolment of transnational private

39 S. Wood et al., 'The Interactive Dynamics of Transnational Business Governance: A Challenge for Transnational Legal Theory' (2015) 6(2) Transnational Legal Theory, pp. 333-69, at 355.

40 Wood et al., n. 36 above, p. 8.

41 P. Verbruggen \& T. Havinga, 'Transnational Business Governance Interactions in Food Safety Regulation: Exploring the Promises and Risks of Enrolment', in Wood et al., n. 2 above, pp. $28-51$.

42 Cafaggi, n. 3 above, pp. 41-2.

43 Partiti, n. 2 above, p. 114.

44 R. Schmidt, 'Protecting the Environment through Sports? Public-Private Cooperation for Regulatory Resources and International Law' (2017) 28(4) European Journal of International Law, pp. 1341-66.

45 B. Eberlein et al., 'Transnational Business Governance Interactions: Conceptualization and Framework for Analysis' (2014) 8(1) Regulation \& Governance, pp. 1-21, at 10-11.

46 S. Wood et al., 'Harnessing TBGIs to Advance Regulatory Quality and Marginalized Actors', in Wood et al., n. 2 above, pp. 363-86, at 371.

47 K. Dingwerth \& P. Pattberg, 'World Politics and Organizational Fields: The Case of Transnational Sustainability Governance' (2009) 15(4) European Journal of International Relations, pp. 707-43. 
regulators is thus closely connected with the substantive, procedural, and governance requirements, and their effective verification. ${ }^{48}$

\section{THE TRANSNATIONAL PRIVATE GOVERNANCE OF DEFORESTATION AND ECOSYSTEM CONVERSION}

This section analyzes transnational private initiatives on deforestation, ecosystem conversion, and associated human rights concerns in the context of a potential TLO to tackle conversion and associated human rights violations. Section 4.1 reviews the tools enacted by individual firms to address FERCs in their value chains. Section 4.2 discusses the aggregate effort of firms and other stakeholders in voluntary certification programmes. Section 4.3 discusses divergent substantive approaches embraced by voluntary sustainability standards.

\subsection{Firm-level Supply-Chain Management, Zero-Deforestation Pledges and Moratoria}

The purchasing practices of firms and their supply-chain management instruments are key in ensuring that transnational economic activity unfolds in compliance with public goals, and should thus be a focal entry point for the intervention of public authorities in the domain of deforestation. Supply-chain management systems are structured operating systems to assess the actual and potential impacts of a firm's activities on concerns such as labour issues, corruption, or deforestation. Within the boundaries of such a system, firms develop plans to manage their impacts and monitor effects; evaluation takes place regularly and adjustments are made to improve performance. ${ }^{49}$ Sustainability supply-chain management addresses and manages sustainability-related practices and risks not just of the firm implementing the system, but of all suppliers and subsuppliers in a value chain. ${ }^{50}$

Sustainability supply-chain management unfolds through the definition of substantive criteria, monitoring and sanctioning obligations that determine conditions for entry and exit from a value chain - often including the most remote upstream tiers. ${ }^{51}$ Supply-chain management systems not only require suppliers to deliver products that are compliant with sustainability-related requirements; they also establish obligations concerning internal reporting, and investigate and remedy non-compliance - including by the suppliers of a supplier - going well beyond the scope of individual transactions. ${ }^{52}$ At the same time, long-term engagement, training, and capacity building is offered to establish across-the-chain traceability, and to monitor origin and conditions of production.

48 Partiti, n. 2 above, pp. 116-7.

49 E. Meidinger, 'Governance Interactions in Sustainable Supply Chain Management', in Wood et al., n. 2 above, pp. 52-76, at 58 .

50 T. Thorlakson, J.F. de Zegher \& E.F. Lambin, 'Companies' Contribution to Sustainability through Global Supply Chains' (2018) 115(9) Proceedings of the National Academy of Sciences, pp. 2072-7.

51 M.P. Vandenbergh, 'The New Wal-Mart Effect: The Role of Private Contracting in Global Governance' (2007) 54(4) UCLA Law Review, pp. 913-70, at 917.

52 F. Cafaggi, 'Regulation through Contracts: Supply-Chain Contracting and Sustainability Standards' (2016) 12(3) European Review of Contract Law, pp. 218-58, at 228. 
These practices may include segregation measures to ensure that compliant products are not mixed with non-compliant products in the value chain or at critical bottlenecks. ${ }^{53}$

Sustainability supply-chain management allows for a much greater extent of governance, oversight and supervision than traditional bilateral contracts, as it considerably limits delegation to suppliers. Supply-chain management empowers downstream chain leaders to govern value chains with sophisticated tools to monitor and enforce contractual obligations. By operating across jurisdictions, supply-chain management has the potential to harmonize applicable requirements in alignment with the most stringent jurisdiction, or potentially with standards going beyond public requirements. ${ }^{54}$ Distance between production and consumption, and the complexity of global value chains, make it difficult to identify responsibilities for deforestation. ${ }^{55}$ Properly structured supply-chain management identifies responsible economic operators and excludes them from supply chains.

Such systems represent the space at firm level where public interest considerations such as ensuring that products associated with negative impacts are not traded - are embedded in corporate activities. Supply-chain management therefore represents an opportunity $^{56}$ for private authority to create a new institutional avenue to diffuse regulation where public authority lacks jurisdiction. This particularly enables the extension to products that originated in other jurisdictions of public, trade-related measures, determining process and production criteria for products to be placed on the market. However, arguably the predominant function of these systems is to tackle and manage operational risk. It is unlikely that firms would fully operationalize public interest goals in supply management without the prospect of liability, and without clear public instructions to harmonize and scale up requirements, and embed interests of affected actors (suppliers, workers, and human rights holders) in firms' decision making. Supply-chain management must therefore be properly leveraged by public authority. If left unhindered, it enables powerful chain leaders to exploit sustainability-related claims, transferring value from suppliers to chain leaders. ${ }^{57}$

Individual buyers and traders are value-chain leaders and creators of management systems that implement sustainability-related commitments in agriculture. ${ }^{58}$ Despite some convergence, individual firms retain their own commitments underpinned by different requirements. ${ }^{59}$ Particularly relevant for this contribution are supply-chain tools

53 F. Cafaggi \& P. Iamiceli, ‘Contracting in Global Supply Chains and Cooperative Remedies’ (2015) 20(2-3) Uniform Law Review, pp. 135-79.

54 Cafaggi, n. 52 above, p. 220.

55 J. Clapp \& C. Scott, 'The Global Environmental Politics of Food' (2018) 18(2) Global Environmental Politics, pp. 1-11, at 3.

56 J.F. Green \& G. Auld, 'Unbundling the Regime Complex: The Effects of Private Authority' (2017) 6(2) Transnational Environmental Law, pp. 259-84, at 272-3.

57 S. Ponte, 'Green Capital Accumulation: Business and Sustainability Management in a World of Global Value Chains' (2020) 25(1) New Political Economy, pp. 72-84, at 73.

58 S. Ponte \& T. Sturgeon, 'Explaining Governance in Global Value Chains: A Modular Theory Building Effort' (2013) 21(1) Review of International Political Economy, pp. 195-223, at 195.

59 C. Richards, G. Lawrence \& D. Burch, 'Supermarkets and Agro-industrial Foods: The Strategic Manufacturing of Consumer Trust' (2011) 14(1) Food, Culture and Society, pp. 29-47. 
that institutionalize deforestation-free sourcing based on formal, publicly announced policies implementing and enforcing deforestation criteria in purchasing contracts. Eighty percent of the international trade in agricultural commodities is handled by four importers - the so-called 'ABCD': Archer-Daniels-Midland, Bunge, Cargill, and Louis Dreyfus. These firms operate as global, cross-sectoral value chain managers. Because of their consolidated vertical integration, they possess enormous power to shape key features of agricultural production and its impacts via supply-chain management. ${ }^{60}$

In recent years, all four of these multinationals have adopted zero-deforestation sourcing commitments in order to ensure that traded commodities are not obtained through conversion of forests and other ecosystems. The individual pledges entered into by the main traders of FERCs are then operationalized via and embedded in supply-chain management. Even on paper these commitments remain ambiguous as firms seldom clarify whether their standard for deforestation is limited to illegal conversion or instead includes any conversion of forest regardless of its legality. Lacking deadlines, most commitments seem limited to refraining from sourcing products obtained from illegally converted forests and do not cover other ecosystems. ${ }^{61}$ For some commodities commitments also include other ecosystems ${ }^{62}$ - in particular, peatland for palm oil ${ }^{63}$ - thereby limiting policy leakage. Issues relating to Indigenous communities, especially in connection with land use, remain conspicuously absent even in firms' broader human rights policies. ${ }^{64}$

Private commitments can be effective where they include rigorous standards, are enforced via third-party audit, and are developed in partnership and collaboration between affected entities rather than imposed top-down. ${ }^{65}$ Corporate commitments, however, are entered into and implemented in the absence of formal incentives and sanctions. Their voluntary status going beyond legal requirements may leave them implemented and monitored ineffectively as downstream companies may not assume any responsibility for the practices of their suppliers. It is unlikely that market forces and consumer pressure alone would spur the main traders to implement and enforce supply-chain systems with a strong environmental and social dimension. The ABCD companies are not brand names subject to consumer pressure. Two of them are

60 J. Clapp, 'ABCD and Beyond: From Grain Merchants to Agricultural Value Chain Managers' (2015) 2(2) Canadian Food Studies, pp. 126-35.

61 E.g., Cargill, 'Cargill Policy on Forests', Feb. 2019, available at: https://www.cargill.com/doc/ 1432136544290/cargill-policy-on-forests.pdf.

62 Cargill, 'Cargill Policy on Sustainable Soy: South American Origins', Feb. 2019, available at: https://www.cargill.com/doc/1432136544508/cargill-policy-on-south-american-soy.pdf.

63 Archer-Daniels-Midland, 'Our Commitment to No Deforestation', available at: https://www.adm.com/ news/stories/our-commitment-to-no-deforestation-no-peat-no-exploitation.

64 E.g., Bunge, 'Labor Policy and Human Rights', available at: https://www.bunge.com/sites/default/files/ bunge_global_labor_policy.pdf.

65 T. Thorlakson, J. Hainmueller \& E.F. Lambin, 'Improving Environmental Practices in Agricultural Supply Chains: The Role of Company-led Standards' (2018) 48(1) Global Environmental Change, pp. $32-42$. 
privately held and hence escape reporting and transparency obligations, and public oversight. ${ }^{66}$ Public intervention therefore remains indispensable.

Firm-level pledges have emerged in an increasingly fragmented landscape of sectoral, single-commodity or geographic commitments made by multi-party coalitions. The Brazilian Soy Moratorium was the first sector-wide commitment with the aim of ending soy-driven deforestation in the Amazon. The ABCD traders and two industry groups of Brazilian processors have committed not to purchase any soy grown on land converted to agriculture after 2006. A monitoring system that relies on remote sensing and satellite mapping enables federal agents, companies, and non-governmental organizations (NGOs) to identify soy farms on converted land. ${ }^{67}$ Information is shared with buyers so that enforcement of the moratorium takes place at the first point of sale, and farmers on illegally converted areas are prevented from selling to signatory traders. ${ }^{68}$ Similarly, the 'G4 Agreement' was entered into by the four largest meatpackers in Brazil, who have agreed not to purchase beef from farms in forested land converted to pasture after $2009 .{ }^{69}$ Both the Soy Moratorium and the cattle agreement have been effective in achieving their goals. ${ }^{70}$

Following the success of these initiatives, a plethora of other pledges appeared covering other FERCs. ${ }^{71}$ Several companies committed to a 'no deforestation, no development on peatland and no exploitation' policy to eliminate palm oil-driven deforestation of High Carbon Stock (HCS) forests, High Conservation Value (HCV) areas, ${ }^{72}$ and peatland, in combination with social human rights considerations for Indigenous people and local communities. ${ }^{73}$ Attempts to move beyond a single commodity or area included a zero-net deforestation commitment by 2020 of the Board of the Consumer Goods Forum, a business organization of more than 400 companies, which, however, are silent on issues relating to Indigenous communities. ${ }^{74}$ The United Nations (UN) New York Declaration on Forests aims to halve the rate of natural forest loss by 2020 and end natural forest loss by $2030 .^{75}$

66 Clapp, n. 60 above, p. 131.

67 H.K. Gibbs et al., 'Brazil's Soy Moratorium: Supply-Chain Governance is Needed to Avoid Deforestation' (2015) 247(6220) Science, pp. 377-78.

68 Y. le Polain de Waroux et al., 'The Restructuring of South American Soy and Beef Production and Trade under Changing Environmental Regulations' (2019) 121 World Development, pp. 188-202.

69 B. Kuepper, M. Piotrowski \& T. Steinweg, 'Cattle-driven Deforestation: A Major Risk to Brazilian Retailers', Chain Reaction Research, 6 Sept. 2018, available at: https:/chainreactionresearch.com/ report/cattle-driven-deforestation-a-major-risk-to-brazilian-retailers.

70 Gibbs et al., n. 67 above.

71 FAO, Zero Deforestation Commitments: A New Avenue towards Enhanced Forest Governance?, Forestry Working Paper 3 (FAO, 2018), p. 5.

72 HCV and HSC are implementation tools created by multi-stakeholder groups to identify areas worthy of conservation. HCV identifies critical areas for biodiversity, ecosystem services, community needs and cultural identity. HCS differentiates forests with a high carbon stock that should be protected from lands with low carbon and biodiversity values that may be developed.

73 For Wilmar: Wilmar, 'No Deforestation, No Peat, No Exploitation Policy', 5 Dec. 2013, available at: https:/www.wilmar-international.com/wp-content/uploads/2012/11/No-Deforestation-No-Peat-NoExploitation-Policy.pdf.

74 Consumer Goods Forum (2010), Board Resolution on Deforestation, available at: http://www.theconsumergoodsforum.com/wp-content/uploads/2017/11/2018-CGF-Resolutions-and-Commitments.pdf.

75 N. 15 above. 
Many of these recent commitments, however, are tokenistic, with limited coverage in terms of both geographical application and commodity scope, for example, by ignoring areas with steadily growing deforestation and often lacking implementation and monitoring strategies. ${ }^{76}$ Like the pledges of individual companies, they deploy different concepts such as zero-net deforestation or zero-gross deforestation. The former includes the possibility to cut forests if new trees are planted elsewhere. This discounts the loss in biodiversity and carbon stock from the destruction of old-growth forests. The latter, instead, entails a complete prohibition of conversion to agricultural land, at least for certain forests. ${ }^{77}$ Varying stringency in both scope and enforcement grants companies ample margin for forum shopping and cosmetic compliance.

\subsection{Voluntary Sustainability Standards}

Predating the development of moratoria, the voluntary sustainability certification movement achieved considerable business uptake where deforestation concerns are rampant, although with differences from sector to sector. ${ }^{78}$ The proliferation of transnational private schemes led to a polycentric configuration in which key actors in the regulation of sustainable production are multi-stakeholder and business organizations. ${ }^{79}$ Private standards attempt holistically to re-embed social and environmental considerations into global capitalism at a time of changing expectations about corporate behaviour. ${ }^{80}$ The establishment of permanent fora allows the exchange of expert information, and the development of best practices and learning on the basis of inclusive deliberative processes. The engagement of various stakeholders helps to resolve internal conflicts and legitimizes non-state, market-driven forms of authority as appropriate arenas where the discipline of value chains is shaped and a new 'logic of appropriateness' emerges. ${ }^{81}$ Especially where no clear obligations exist, such as in the domain of deforestation connected with economic activities, rules about appropriate corporate behaviour appear and become institutionalized through interactions between multiple interconnected rulemakers. ${ }^{82}$ If many actors - including, importantly, private standard setters - adopt a coherent conceptualization of societally expected corporate behaviour, a limitative process of constitutionalization emerges. Evading norms and engaging in

76 R.K. Larsen et al., 'Hybrid Governance in Agricultural Commodity Chains: Insights from Implementation of "No Deforestation, No Peat, No Exploitation" (NDPE) Policies in the Palm Oil Industry' (2018) 183 Journal of Cleaner Production, pp. 544-54.

77 FAO, n. 71 above, p. 10.

78 E.g., there are no programmes certifying cattle: G. Auld, Constructing Private Governance: The Rise and Evolution of Forest, Coffee, and Fisheries Certification (Yale University Press, 2014), pp. 225-30.

79 K.W. Abbott, 'The Transnational Regime Complex for Climate Change' (2012) 30(4) Environment and Planning C: Government \& Policy, pp. 571-90.

80 T. Bartley, 'Institutional Emergence in an Era of Globalisation: The Rise of Transnational Private Regulation of Labor and Environmental Conditions' (2007) 113(2) American Journal of Sociology, pp. 297-351, at 299.

81 S. Bernstein \& B. Cashore, 'Can Non-state Global Governance be Legitimate? An Analytical Framework' (2007) 1(2) Regulation \& Governance, pp. 347-71.

82 T.D. Lytton, 'The Taming of the Stew: Regulatory Intermediaries in Food Safety Governance' (2017) 660 Annals of the American Academy of Political and Social Science, pp. 78-92, at 89. 
undesirable behaviour becomes harder, as the authority of rule-defining conduct increases along with its growing acceptance. ${ }^{83}$

Private regimes, however, also reflect and perpetuate asymmetries in power and resources in value chains. ${ }^{84}$ Marginalized actors such as farm-workers, smallholders and Indigenous communities are rarely included in standard setting. ${ }^{85}$ Private regimes often embrace, rather than challenge, a dominant narrative that trade and voluntary market mechanisms contribute to sustainability. ${ }^{86}$ Proliferation complicates implementation, contributes to confusion among consumers, public authorities and civil society groups, and increases risks of a race to the bottom, forum shopping and greenwashing. ${ }^{87}$ Overlapping regimes compete for acceptance and trust from consumers and firms. ${ }^{88}$ Diversity of schemes is reflected in standard-setting organizations, which span from those that represent only industry actors to organizations representing the interests of affected actors and civil society under inclusive procedures for standard setting and governance. ${ }^{89}$ Such general trends are unlikely to change without public intervention as schemes lack incentives to converge. ${ }^{90}$ Thus, convergence around legality verification in timber certification depended on EU intervention with the Forest Law Enforcement, Governance and Trade (FLEGT) plan and the EUTR. ${ }^{91}$

This notwithstanding, private standards tackling environmental impacts of agricultural commodities and deforestation concerns in particular have served as a laboratory for new regulatory solutions. ${ }^{92}$ Public support for private standards increases when they can successfully assist public authority in enforcing domestic policies. ${ }^{93}$ The regulatory capabilities of standards are appealing to public regulators in consuming countries. Certification can be effective in monitoring compliance with requirements in jurisdictions where public authorities have neither the capacity nor the

83 O. Perez \& O. Stegmann, 'Transnational Networked Constitutionalism' (2018) 45(S1) Journal of Law and Society, S135-S162.

84 B. Daviron \& S. Ponte, The Coffee Paradox: Global Markets, Commodity Trade and the Elusive Development (Zed Books, 2005).

85 E.A Bennett, 'Who Governs Socially-oriented Voluntary Sustainability Standards? Not the Producers of Certified Products' (2017) 91(1) World Development, pp. 53-69.

86 J. Clapp, 'The Trade-ification of the Food Sustainability Agenda' (2016) 44(2) Journal of Peasant Studies, pp. 335-53; Bartley, n. 80 above, p. 338.

87 L. Fransen, 'Multi-stakeholder Governance and Voluntary Programme Interactions: Legitimation Politics in the Institutional Design of Corporate Social Responsibility' (2012) 10(1) Socio-Economic Review, pp. 163-92.

88 J. Reinecke, S. Manning \& O. von Hagen, 'The Emergence of a Standards Market: Multiplicity of Sustainability Standards in the Global Coffee Industry' (2012) 33(3) Organisation Studies, pp. 791-814.

89 For timber: T. Cadman, Quality and Legitimacy of Global Governance: Case Lessons from Forestry (Palgrave Macmillan, 2011).

90 T.M. Smith \& M. Fischlein, 'Rival Private Governance Networks: Competing to Define the Rules of Sustainability Performance’ (2010) 20(3) Global Environmental Change, pp. 511-22.

91 C. Overdevest \& J. Zeitlin, 'Assembling an Experimentalist Regime: Transnational Governance Interactions in the Forest Sector' (2014) 8(1) Regulation \& Governance, pp. 22-48.

92 C. Overdevest, 'Comparing Forest Certification Schemes: The Case of Ratcheting Standards in the Forest Sector’ (2010) 8(1) Socio-Economic Review, pp. 47-76.

93 B. Cashore \& M. Stone, 'Does California Need Delaware? Explaining Indonesian, Chinese, and United States Support for Legality Compliance of Internationally Traded Products’ (2014) 8(1) Regulation \& Governance, pp. 43-79, at 59. 
authority to do so. Standards thus usefully feed into the monitoring and enforcement stage. In addition, schemes are used as a reference criterion for sustainable products, such as in public procurement. ${ }^{94}$ Schemes can also specify steps that firms must take in the context of their non-financial due diligence. In both cases schemes are directly or indirectly enrolled and leveraged by public authority because of their implementing capacity, which results from expert and multi-stakeholder work in giving direct meaning to sustainability of production.

Certification is widely used to show compliance with zero-deforestation pledges and make claims about impacts on ecosystems and people. Over time, the uptake of schemes by firms has become linked to a need to manage relations in value chains, define rights and obligations, and implement due diligence and legality requirements. ${ }^{95}$ In addition to substantive obligations regarding product features, private schemes provide for management processes to be integrated within the practices of downstream firms. Within supply-chain management systems, requirements established by private standards in combination with third-party auditing complement individual standards and monitoring of the chain leader, thereby ensuring across-the-chain uniformity, traceability, and segregation. ${ }^{96}$ Standards are based on, and interact with, local, national, and customary norms in the contexts of application, which shape their rules and determine their effectiveness. $^{97}$ They also interact with policies and laws from consuming countries. As offering implementing tools to firms for due diligence-based obligations is central to schemes' regulatory activities, standards are particularly receptive to public measures that establish non-financial due diligence.

\subsection{Forest and Ecosystem Conversion, Rights of Indigenous Communities in Private Standards and the Effects of Benchmarking}

The proliferation described above results in schemes that tackle varying aspects of deforestation. While procedural and governance aspects have been extensively studied, ${ }^{98}$ the focus here is on the substance of the standards. It is doubtful whether a scheme exists that can be used as convincing evidence of zero deforestation if the target is understood to include forests, ecosystem conversion, and associated human rights violations. Potential concerns about the quality of private auditing aside, ${ }^{99}$ extensive loopholes in deforestation criteria reduce the ability of private standards to tackle deforestation effectively. ${ }^{100}$ They also limit the extent to which standards may foster

94 Directive 2014/24/EU on Public Procurement [2014] OJ L 94/65, Arts 42, 43 and Annex VII.

95 T. Bartley, 'Transnational Governance and the Re-centred State: Sustainability or Legality' (2014) 8(1) Regulation \& Governance, pp. 93-109.

96 Cafaggi, n. 52 above.

97 Bartley, n. 31 above.

98 Cadman, n. 89 above.

99 R.M. Locke, The Promise and Perils of Private Power: Promoting Labour Standards in a Global Economy (Cambridge University Press, 2013), pp. 162ff.

${ }^{100}$ H. van der Ven, C. Rothacker \& B. Cashore, 'Do Eco-labels Prevent Deforestation? Lessons from Non-state Market Driven Governance in the Soy, Palm Oil, and Cocoa Sectors' (2018) 52 Global Environmental Change, pp. 141-51, at 149. 
a consistent message about normatively desirable corporate conduct and contribute to its operationalization. There is therefore a need to coordinate and streamline regulatory approaches and harmonize key criteria around key indicators of deforestation, such as definitions and identification of forests and ecosystems. ${ }^{101}$

The Forest Stewardship Council (FSC) delivers the most stringent standard for certification of timber products. Among other requirements concerning the sustainable management of forests and plantations, it prohibits in principle conversion of natural forests to other land uses regardless of legality. ${ }^{102}$ However, the popular 'Controlled Wood' programme allows non-FSC compliant material to be mixed with compliant timber and certified as 'FSC Mix' upon a risk assessment by the firm. As auditors verified only marginally how risk assessment was performed, illegally harvested woods from boreal forests have been certified, including those from intact forest landscapes ${ }^{103}$ - unbroken natural forest landscapes with the highest conservation value. The competitor Programme for the Endorsement of Forest Certification (PEFC) employs the definition of 'forest' of the Food and Agriculture Organization (FAO) and allows for conversion under 'justified circumstances'. The PEFC allows certification of plantations on areas converted before 2011, ${ }^{104}$ whereas the relevant cut-off date for plantations under the FSC dates back to $1994 .{ }^{105}$ The Sustainable Forestry Initiative (SFI) allows change in forest cover type where it complies with legal requirements, apart from native forests. ${ }^{106}$

In other domains the Round Table on Responsible Soy Association (RTRS) prohibits both legal and illegal conversions of critical biodiversity hotspots after 2009, and conversion of natural forests that occurred after June 2016. ${ }^{107}$ However, forests are limited to 'native forests', which are identified under requirements less demanding than those under the FAO definition. ${ }^{108}$ The Roundtable on Sustainable Palm Oil (RSPO) until 2018 prohibited the clearing of primary forests with 2005 as a cut-off date, but did allow conversion of secondary forests and peat forests. The revised 2018 standards prohibit conversion and degradation of peatland, HCV areas and HCS forests cleared after 15 November 2018. ${ }^{109}$ UTZ standards, relevant for cocoa production in western Africa, used to distinguish between primary and secondary forests. Primary forests ${ }^{110}$ were protected by barring certification if conversion had

101 T.A. Gardner et al., 'Transparency and Sustainability in Global Commodity Supply Chains' (2019) 121 World Development, pp. 163-77, at 168.

102 FSC, 'FSC International Standard: FSC Principles and Criteria for Forest Stewardship', FSC-STD-01-001 V5-2 EN, July 2015, para. 6.9.

103 Interview with former certification programme manager (on file with the author).

104 PEFC, 'PEFC Benchmark Standard on Sustainable Forest Management: Requirements', PEFC ST 1003:2018, 28 Nov. 2018, Appendix 1.

105 FSC, n. 102 above, para. 6.10.

106 SFI, 'SFI 2015-2019 (Extended through December 2021) Forest Management Standard', Jan. 2015, Performance Measure 1.2.

107 RTRS, 'RTRS Standard for Responsible Soy Production', Version 3.0, 2 June 2016, Principle 4.4.2.

108 Ibid., p. 38.

109 RSPO, 'Principles and Criteria for the Production of Sustainable Palm Oil (2018)', Criteria 7.7 and 7.12.

110 FAO, 'Forest Resources Assessment 2015: Terms and Definitions', FRA Working Paper 180, p. 7, available at: http://www.fao.org/3/ap862e/ap862e00.pdf. 
occurred before 2008. For secondary forests certification of farms obtained on lawfully converted secondary forests was permitted. ${ }^{111}$ As the distinction raised criticism and was difficult to implement in practice, following the merger in 2018 with the Rainforest Alliance, the new 2020 Rainforest Alliance standard prohibits conversion of all ecosystems with a 2014 cut-off date. ${ }^{112}$

In the context of rights relating to Indigenous communities, the requirements for sustainability standards are traceable to international instruments and the evolution of customary international law. Procedural rights are essential for addressing the negative impact of agricultural development on such communities. ${ }^{113}$ The development of the notion of FPIC is a necessary element in respecting substantive Indigenous rights connected with their land and natural resources use. FPIC goes beyond a right to consultation and identifies a right not to be removed or relocated without consent. It is recognized as a legal norm that imposes clear affirmative duties and obligations on states. ${ }^{114}$ A right to consultation and consent according to their customs and traditions has been applied also to communities that may not be regarded as Indigenous. ${ }^{115}$ International human rights bodies have clarified that FPIC is part of state obligations under relevant treaties. ${ }^{116}$ Private schemes extend the protection of Indigenous landrelated rights from state activities to include private activities. Approaches and outcomes, however, differ.

Since its inception, the FSC Principles and Criteria have recognized the legal and customary rights of Indigenous peoples to own, use and manage their land, and recognized that they control forest management unless this has been delegated with free and informed consent. The addition of prior consent in accordance with evolving international obligations occurred in 2012, parallel with the establishment of the Permanent Indigenous Peoples Committee. ${ }^{117}$ The FSC extends FPIC to local communities impacted by forest management. However, FPIC must be obtained only prior to the implementation of management activities, and not before the issuance of a concession. ${ }^{118}$ FSC Canada has gone further and complemented the FSC three-chamber

111 UTZ, 'UTZ Guidance Document: Nature Protection', Version 1.0, Aug. 2016, available at: https:/utz.org/wp-content/uploads/2015/12/Nature-protection-guidance-document-UTZ.pdf.

112 Interview with certification programme manager (on file with the author).

113 M. Brunori, 'Protecting Access to Land for Indigenous and Non-Indigenous Communities: A New Page for the World Bank?' (2019) 32(4) Leiden Journal of International Law, pp. 501-16, at 512.

114 International Labour Organization, Convention 169 on Indigenous and Tribal Peoples, Geneva (Switzerland), 27 June 1989, in force 5 Sept. 1991, available at: https:/www.refworld.org/docid/ 3ddb6d514.html; UN General Assembly (GA) Res. 61/295 'Declaration on the Rights of Indigenous Peoples’ (13 Sept. 2007), available at: https:/www.un.org/development/desa/indigenouspeoples/wpcontent/uploads/sites/19/2018/11/UNDRIP_E_web.pdf.

115 Saramaka People v. Suriname, Inter-American Court of Human Rights, Interpretation of the Judgment on Preliminary Objections, Merits, Reparations and Costs, 12 Aug. 2008, IACHR Series C No. 185, para. 41.

116 UN Committee on Economic, Social and Cultural Rights, 'General Comment No. 21: Right of Everyone to Take Part in Cultural Life', 20 Nov. 2009, UN Doc. E/C.12/GC/21.

117 FSC, 'International Standard: FSC Principles and Criteria', FSC-STD-01-001 V5-0 EN, Feb. 2012.

118 FSC, 'Guidelines for the Implementation of the Right to FPIC', Version 1. 30 Oct. 2012, p. 6. 
system with a fourth Indigenous chamber. ${ }^{119}$ This has reinforced the rights of Indigenous communities through the introduction of Indigenous Cultural Landscapes - for which Indigenous peoples have stewardship responsibility - as a means to implement FPIC and as an alternative forest management model. Canadian Indigenous communities affected by FSC certification enjoy greater control over, and participation in, the management of their resources than under national law. ${ }^{120}$ FSC operations in other countries have been less successful, especially where Indigenous rights are not adequately recognized under national law; in Indonesia, FSC certificates were granted despite land leases having been obtained without consent or consultation with such communities. ${ }^{121}$ In contrast, certifications such as the SFI do not mention FPIC or traditional land uses, but refer only to respecting traditional forest-related knowledge, and to protect spiritually, historically, or culturally important sites. ${ }^{122}$

For commodities other than timber, the importance of FPIC is magnified by the relatively greater impact of large-scale agribusiness and land concessions on Indigenous livelihood and land-use rights. ${ }^{123}$ RSPO standards have included FPIC since their first version, and the rights of Indigenous communities were reinforced in subsequent revisions. ${ }^{124}$ This was not an easy process, as the RSPO faced criticism from Indonesian producers - who defected to a more relaxed public certification programme - when it required FPIC to be obtained before new plantings. ${ }^{125}$ Also, in Malaysia, national rules that limit the customary rights of communities clash with certification requirements. This has led companies to insist that compliance with national laws suffices for certification. ${ }^{126} \mathrm{HCV}$ areas include areas crucial for cultural identity which must be identified through participatory engagement with affected communities. Schemes protecting HCV areas thus offer additional venues to account substantively and procedurally for Indigenous communities. $^{127}$

119 C. Tollefson, F. Gale \& D. Haley, Setting the Standard: Certification, Governance and the Forest Stewardship Council (UBC Press, 2008).

${ }^{120}$ N. Oman, 'Private Ordering and Transnational Social Justice: The Forest Stewardship Council's Advocacy of Free, Prior and Informed Consent', in Wood et al., n. 2 above, pp. 315-37, at 322-3 and 333.

${ }^{121}$ M. Colchester, 'Do Commodity Certification Systems Uphold Indigenous Peoples' Rights? Lessons from the Roundtable on Sustainable Palm Oil and Forest Stewardship Council', in P. Castka \& D. Leaman (eds), Policy Matters 2016: Certification and Biodiversity (International Union for Conservation of Nature and Natural Resources, 2016), pp. 150-65, at 154.

122 SFI, n. 106 above, Objective 8.

123 Colchester, n. 121 above, p. 153.

124 J. Meadows, M. Annandale \& L. Ota, 'Indigenous Peoples' Participation in Sustainability Standards for Extractives' (2019) 88(1) Land Use Policy, pp. 1-13, at 8.

125 C. Filer, S. Mahanty \& L. Potter, 'The FPIC Principle Meets Land Struggles in Cambodia, Indonesia and Papua New Guinea' (2020) 9(3) Land, pp. 1-21.

${ }^{126}$ R. Bulan, 'Legal Pluralism in Sarawak: An Approach to Customary Laws on Their Own Terms under the Federal Constitution', in M. Colchester \& S. Chao (eds), Divers Paths to Justice: Legal Pluralism and the Rights of Indigenous Peoples in Southeast Asia (Forest Peoples Programme, 2011), pp. 40-65.

${ }^{127}$ E. Brown et al. (eds), Common Guidance for the Identification of High Conservation Values (HCV Resource Network, 2013), pp. 19-20. 
In line with the various instruments on FPIC, and the United Nations Guiding Principles on Business and Human Rights (UNGPs), ${ }^{128}$ schemes should also consider effective mechanisms for remediation and redress. Only a few standards, however, have established grievance mechanisms, and doubts persist about whether these satisfy procedural human rights requirements and the principles of accessibility, predictability, equitability, transparency, and provide for continuous learning and dialogue. ${ }^{129}$ Testifying to these concerns, two complaints were lodged recently before the National Contact Points for the Organisation for Economic Co-operation and Development (OECD) Guidelines for Multinational Enterprises, challenging commitments in respect of Indigenous rights, the effective presence of FPIC and effectiveness of grievance mechanisms of Bonsucro and the RSPO ${ }^{130}$ Both cases are still pending, and in the RSPO case the parties have agreed the terms for a legal review by the RSPO complaint panel and an action plan. ${ }^{131}$

Generally, a slow scaling-up process of deforestation-related requirements can be observed within some schemes. Private benchmarking across standards has also contributed to this upward alignment. A recent focus on ecosystem conversion regardless of its legality is traceable to the 2019 establishment of the Accountability Framework Initiative (AFI) by international NGOs. ${ }^{132}$ The AFI supports companies in protecting forests and natural ecosystems in their value chains. ${ }^{133}$ After the proliferation of moratoria, pledges and standards, a need arose among the industry to obtain guidance concerning what NGOs would consider as 'deforestation-free' value chains. ${ }^{134}$ The AFI addresses this need not through certification but by elaborating common principles, operational guidance, and extensive definitions of natural forests and natural ecosystems, which moves the focus of protection from certain types of forest and a few ecosystems to all natural ecosystems. The AFI embraces a no-conversion approach at the landscape level to ensure that a company's production, sourcing, and financial investment do not cause or contribute to the loss of any natural ecosystem, including but not limited to forests. ${ }^{135}$ It also offers methodologies for the identification of natural ecosystems and the implementation of supply-chain management tools.

While individual firms can directly employ the framework or use it as a benchmark against which to assess certifications, the AFI has found its way into private standardization as well. The Rainforest Alliance's 2020 revision has incorporated the AFI's

128 Human Rights Council, 'Guiding Principles on Business and Human Rights: Implementing the United Nations' "Protect, Respect and Remedy” Framework', 21 Mar. 2011, UN Doc. A/HRC/17/31 (UNGPs), Principles 28-31.

129 Colchester, n. 121 above, p. 158.

130 Before the Swiss NCP: TuK Indonesia v. Roundtable on Sustainable Palm Oil (RSPO); before the United Kingdom NCP: IDI, EC and LICADHO v Bonsucro.

131 NCP of Switzerland, 'Final Statement in the Specific Instance regarding the Roundtable for Sustainable Palm Oil submitted by TuK Indonesia', 5 June 2019.

132 Available at: https://accountability-framework.org.

133 AFI, 'Core Principles', 2019, Principle 1.

134 Interview with certification programme manager (on file with the author).

135 AFI, n. 133 above, Principle 1.2. 
no-conversion approach and relevant concepts and definitions, ${ }^{136}$ and other standard setters are in the process of including relevant aspects of the AFI approach in their requirements. ${ }^{137}$ Beyond benchmarking, the AFI thus also exercises the functions of a 'soft' meta-regulator. Differing from pre-existing private meta-regulators in the domain of sustainability such as ISEAL, the AFI is not concerned with procedural aspects of standard setting, ${ }^{138}$ impact measurement and evaluation, ${ }^{139}$ but ratchets up substantive elements of voluntary sustainability standards by closing definitional loopholes. Additionally, the AFI contributes to extending and possibly harmonizing requirements that affect Indigenous communities. It has produced among the broadest guidance on the rights of such communities, requiring FPIC prior to any activity that may affect such rights, land, livelihood and food security. Failing to do so requires the suspension of all activities and granting remediation. ${ }^{140}$ The AFI has also elaborated extensive guidance on remedies, not only for adverse human rights impacts, but also for deforestation and conversion. ${ }^{141}$

\section{TACKLING GLOBAL DEFORESTATION THROUGH MANAGEMENT-BASED REGULATION}

The discussion in Section 4 reveals an emerging TLO that disciplines deforestation, conversion, and associated violations of Indigenous community rights that are connected with trade in agricultural commodities. This TLO, however, is currently composed of various overlapping and even conflicting private instruments structured along value chains. It has limited coverage in terms of both geographical application and concerns tackled. It follows the supply chains of the firms which voluntarily embed these concerns in their management systems. It is limited to protecting only certain ecosystems (most often natural forests), with very different definitions and in relation to a few commodities only. While timber, palm oil, and soy are often covered, beef (including leather), pulp and paper, and maize rarely are, even though they are equally high-risk commodities for global deforestation. Finally, an Indigenous rights-related dimension is not always present, with limited protection of procedural rights such as FPIC and weak, if not altogether absent, remediation mechanisms. Substantively, the nascent TLO suffers from divergence and indeterminacy in defining ecosystems worthy of protection and in identifying a human rights standard for Indigenous communities. Corporate management systems lack rigorous and uniform standards, and their operation in the absence of liability prioritizes operational risks over environmental and social risk.

\footnotetext{
${ }^{136}$ Interview with certification programme manager (on file with the author).

137 Ibid.

138 ISEAL, 'Setting Social and Environmental Standards: ISEAL Code of Good Practice', Version 6.0, 2014.

139 ISEAL, 'Assessing the Impacts of Social and Environmental Standards Systems: ISEAL Code of Good Practice', Version 2.0, 2014.

140 AFI, 'Operational Guidance on Free, Prior and Informed Consent', 2019, p. 4; AFI, n. 133 above, Principle 2.2.3.

141 AFI, 'Operational Guidance on Environmental Restoration and Compensation', 2019, p. 4; AFI, n. 133 above, Principle 9.1.
} 
In the domain of timber legality, the FLEGT initiative and the EUTR have generated interactions with several governance actors, resulting in an aligned and 'joined-up' transnational regime. ${ }^{142}$ This has been achieved by stimulating convergence among actors and initiatives, and by diffusing consistent requirements. The EUTR set-up can be further leveraged to align voluntary private initiatives and corporate practices across value chains. Cooperation and engagement at the bilateral level should continue through an institutional structure along the lines of the Voluntary Partnership Agreements (VPAs) extended to other commodities. The involvement of local stakeholders in the precise and context-specific definition of no-conversion criteria ensures input legitimacy for non-EU affected actors. ${ }^{143}$ In parallel, as for the EUTR, a mandatory regime should be established requiring firms to place FERCs and derived products on the EU market lawfully only if they demonstrate that goods do not originate from land obtained via the conversion of natural forests and natural ecosystems. Economic actors must also demonstrate that goods are not produced in direct or indirect violation of land-related human rights. Such an obligation would be operationalized in firms' management systems via non-financial due diligence in line with HRDD.

A FERC measure could thus be based on Article 114 TFEU, in conjunction with Article 192 TFEU. Even if it were to generate extra-EU implications, EU intervention is legitimate and desirable. Under World Trade Organization (WTO) law, countries retain the right to ensure that their market does not contribute to condemned practices. ${ }^{144}$ Countries can unilaterally protect exhaustible natural resources, in particular, after multilateral engagement has failed to deliver results. ${ }^{145} \mathrm{~A}$ large and damaging EU environmental footprint (mostly happening outside EU borders, including the generation of its most negative effects) could make the EU an 'accomplice' in global deforestation. ${ }^{146}$ Such a regulatory intervention should also be accompanied by policies that aim to reduce internal consumption, ensuring that non-EU interests are taken into account, continuing multilateral engagement in REDD+, and providing economic incentives to developing countries for forest and ecosystem preservation.

The complementarity of private authority and public measures is visible in the mobilization by legislators, particularly EU lawmakers, of transnational private regimes for sustainability, ${ }^{147}$ and in the deployment of regulatory approaches that leverage corporate management systems in value-chain regulation, such as in the

142 J. Zeitlin \& C. Overdevest, 'Experimentalist Interactions: Joining up the Transnational Timber Legality Regime' (2021) 15(3) Regulation \& Governance, pp. 686-708.

${ }^{143}$ For interest inclusion in measures with extraterritorial implications: J. Hadjiyianni, The EU as a Global Regulator for Environmental Protection: A Legitimacy Perspective (Hart, 2019).

${ }^{144}$ United States - Measures concerning the Importation, Marketing and Sale of Tuna and Tuna Products, Appellate Body Report, WT/DS381/AB/R, adopted 16 May 2012, para. 377.

145 United States - Import Probibition of Certain Shrimp and Shrimp Products, Appellate Body Report, WT/DS58/AB/R, adopted 12 Oct. 1998, para. 166. Assessing WTO compatibility of non-financial due diligence: E. Partiti, 'Regulating Trade in Forest-risk Commodities' (2020) 54(1) Journal of World Trade, pp. 31-58.

146 J. Scott, 'The Global Reach of EU Law', in M. Cremona \& J. Scott (eds), EU Law Beyond EU Borders: The Extraterritorial Reach of EU Law (Oxford University Press, 2019), pp. 47-57.

147 Partiti, n. 2 above. 
domain of timber legality. Two distinct but interconnected agents of interaction that exploit the complementarity of private authority and public action are discussed here. They are EU authorities' enrolment of corporate management through the prescription of mandatory non-financial due diligence, and EU authorities' indirect enrolment and meta-regulation of private standards through the definition of no-conversion criteria. Section 5.1 discusses due diligence in the context of the EUTR. Section 5.2 presents the framework for non-financial due diligence as outlined by the UNGPs. Section 5.3 discusses its extension to deforestation and ecosystem conversion, and its potential impact on supply-chain management. Section 5.4 discusses implications for private standards and outlines regulatory options for key definitions.

\subsection{Non-Financial Due Diligence and Trade in Timber}

The EUTR creates and enforces a regime that restricts the placing of products on the market, while incentivizing and endorsing firm-level systems of verification and risk management. ${ }^{148}$ Under the FLEGT plan, bilateral agreements with a permanent institutional setting for certification of timber legality were established in producing countries, including mechanisms for dialogue with governments and civil society. ${ }^{149}$ In parallel, the EUTR prohibits the placing on the internal market of illegally harvested timber or derived products. ${ }^{150}$ Economic operators that place these products on the EU market must establish due diligence systems for timber legality. ${ }^{151}$ Private standards can be used in the context of firms' due diligence assessment, for example, to obtain information about origin, but certification does not confer the presumption of legality. ${ }^{152}$

Due diligence systems must be capable of allowing operators to access information about origin and legality; they must contain risk assessment procedures enabling operators to evaluate the risk of illegal timber in their value chains; also, in the presence of non-negligible risk that illegal timber is handled, they must provide for risk mitigation procedures. ${ }^{153}$ Risk mitigation measures include requests for additional information, the possible use of third-party or independent audits in the country of origin, and the use of scientific methods for timber identification. If risk is not reduced to a negligible level, operators must refrain from marketing in the EU and disengage from suppliers that cannot guarantee negligible risk. ${ }^{154}$ In combination with the VPAs, the EUTR has had a positive impact on illegal logging. At the same time it has contributed to improving the uptake and requirements of forestry certifications. ${ }^{155}$

\footnotetext{
148 Bartley, n. 95 above, p. 102.

149 Council Regulation (EC) No. 2173/2005 on the Establishment of a FLEGT Licensing Scheme for Imports of Timber into the European Community [2005] OJ L 347/1.

150 EUTR, n. 7 above, Art. 4.1.

151 Ibid., Art. 4.2.

152 Partiti, n. 2 above, p. 111.

153 EUTR, n. 7 above, Art. 6.

154 Expert Group on the EU Timber Regulation and the Forest Law Enforcement, Governance and Trade Regulation, Guidance Document on Risk Mitigation Measures.

155 Overdevest \& Zeitlin, n. 91 above.
} 
Non-financial due diligence, as in the EUTR, is a form of management-based regulation leveraging corporate knowledge and resources. ${ }^{156}$ Responsibility for decision making is allocated to entities with the best information about specific risks that are equipped to control and enforce via supply-chain management systems. ${ }^{157}$ The choice of non-financial due diligence in the domain of timber legality is not surprising: management-based approaches are preferred where risks are hard to assess (in this case because of jurisdictional limitations and the impossibility of distinguishing between compliant and non-compliant products) and in the presence of many diverse firms. As with management-based regulation, non-financial due diligence requires businesses to develop their internal processes to respond to risks within the boundaries of management practices identified by the regulator. Firms engage in self-regulation, planning, information collection, and supply-chain management. ${ }^{158}$ Where non-financial due diligence is implemented, management systems at the firm level become the interface between public and private values, and between the goals and operations of society and the organization. ${ }^{159}$

Non-financial due diligence enrols the regulatory capacity of private firms. Public authorities make use of firms' capabilities but, unlike delegation of regulatory functions, exercise only a limited degree of control. Firms can thus easily 'game' nonfinancial due diligence-based regulation where it merely prescribes broad principles to be implemented internally. ${ }^{160}$ Constraints must therefore be provided by specifying procedures, providing incentives and sanctions. Furthermore, corporate decision making in the public sphere must be complemented with a procedural dimension ensuring alignment with public goals while accounting for the interests of those affected, and with redress mechanisms enhancing the accountability of corporations as actors of global governance. ${ }^{161}$ This is particularity crucial where corporations deal with multifaceted phenomena affecting stakeholders in countries outside the regulating jurisdictions, and which may directly touch upon their human rights.

\subsection{Human Rights Due Diligence and the UN Guiding Principles}

Forms of non-financial due diligence are employed by corporations to assess the impacts of their operations on human rights and the environment. ${ }^{162}$ These business

156 J. Braithwaite, 'Enforced Self-regulation: A New Strategy for Corporate Crime Control' (1982) 80(7) Michigan Law Review, pp. 1466-507.

157 C.L. Ford, 'New Governance, Compliance and Principles-based Securities Regulation' (2008) 45(1) American Business Law Review, pp. 1-60, at 28.

158 C. Coglianese \& D. Lazer, 'Management-based Regulation: Using Private Management to Achieve Public Goals' (2003) 37(4) Law \& Society Review, pp. 691-730.

159 M. Power, Organised Uncertainty: Designing a World of Risk Management (Oxford University Press, 2007), p. 42.

${ }^{160}$ C. Coglianese, 'Management-based Regulation: Implications for Public Policy', in OECD, Risk and Regulatory Policy: Improving the Governance of Risk (OECD, 2007), pp. 160-1.

161 R.B. Stewart, 'Remedying Disregard in Global Regulatory Governance: Accountability, Participation, and Responsiveness' (2014) 108(2) American Journal of International Law, pp. 211-70.

162 C.L. Reichardt, 'Due Diligence Assessment of Non-financial Risk: Prophylaxis for the Purchaser' (2006) 31(4) Resources Policy, 193-203. 
practices, and an emerging case law which confirms that business has a duty of care in its activities and towards affiliates, were 'codified' in the notion of HRDD as provided in the UNGPs as an integral element of the 'moral responsibility' of business to respect human rights. ${ }^{163}$ HRDD 'comprises an ongoing management process that a reasonable and prudent enterprise needs to undertake, in the light of its circumstances to meet its responsibility to respect human rights'. ${ }^{164}$ It constitutes a global and overarching expectation for all businesses. ${ }^{165}$

HRDD allocates responsibilities for corporate activities that impact on human rights, going beyond the relation between a parent company and its subsidiaries. A firm is potentially responsible for all human rights impacts stemming from any commercial and non-commercial relation it has with business entities, governments, employees, customers, and affected human rights holders. ${ }^{166}$ Corporations are linked to adverse human rights impacts not only through their own activities, but also as a consequence of their business relationships. ${ }^{167}$ In the first scenario, corporations directly cause negative impacts, and should take steps to cease or prevent such impact via HRDD, and offer remediation. Businesses contribute to negative human rights impacts where impact is co-generated with another entity or via a third entity. A company should take necessary steps to cease or prevent its contribution, and use its leverage to mitigate remaining impacts. In the second scenario, a direct link can be established between adverse impacts and a company's operations, products or services through commercial relations with other companies. Remediation is not expected but the company should use its economic and non-economic leverage to prevent or mitigate adverse impacts. ${ }^{168}$ This last scenario involves entities with which the company does not have direct contractual relationships, such as the supplier of a supplier, up to the most remote tiers where resources and raw materials are produced and extracted. Responsibility extends to failure to exercise leverage over suppliers who do not prevent or tackle adverse impacts. ${ }^{169}$

HRDD confers upon companies transnational regulatory functions in their value chains. Corporations have to manage the possible impact stemming from their actions, products and commercial relations. Such functions require corporations to monitor, sanction and discipline other firms in their value chains. ${ }^{170}$ Particularly with regard

163 R. Mares, 'Global Corporate Social Responsibility, Human Rights and the Law: An Interactive Regulatory Perspective on the Voluntary-Mandatory Dichotomy' (2010) 1(2) Transnational Legal Theory, pp. 212-85.

164 UN, Office of the High Commissioner on Human Rights (OHCHR), The Corporate Responsibility to Respect Human Rights: An Interpretive Guide (UN, 2012), p. 6.

165 UN, OHCHR, Frequently Asked Questions about the Guiding Principles on Business and Human Rights (UN, 2014), pp. 9-10.

166 UNGPs, n. 128 above, Principle 11.

167 Ibid., Principle 13.

168 Ibid., Principle 19 and commentary.

169 S. Wood, 'The Case for Leverage-based Corporate Human Rights Responsibility' (2012) 22(1) Business Ethics Quarterly, pp. 63-98.

170 G.A. Sarfaty, 'Shining Light on Global Supply Chains' (2015) 56(2) Harvard International Law Journal, pp. 419-63, at 435 . 
to impacts generated by suppliers, corporations have to engage, leverage and 'sanction' them by discontinuing economic relations where firms cannot guarantee compliance with human rights. This special conferral of regulatory power is enabled and circumscribed by procedural requirements that must be embedded in supply-chain management. These include requirements to seek information about human rights risks, evaluate risks and devise means to reduce them, report to the general public, and provide remedies to those affected. To meet the UNGPs, corporations have to adopt, design and continuously assess, evaluate and improve managerial risk-based processes. ${ }^{171}$ The risks covered by HRDD are, however, not financial or reputational risks for the firm concerned, but refer to the risk that human rights are negatively affected by business activities. ${ }^{172}$ The UNGPs also require meaningful consultation with potentially affected groups and other stakeholders in identifying and assessing actual and potential adverse human rights impact. ${ }^{173}$

Various standards provide guidance on how to operationalize due diligence in practice, the most important of which are various OECD Guidelines ${ }^{174}$ providing sectoral implementation of the 2011 OECD Guidelines for Multinational Enterprises, which are aligned with the UNGP framework. ${ }^{175}$ The OECD Guidance for Responsible Business Conduct requires firms to 'understand and address barriers arising from the enterprise's way of doing business that may impede the ability of suppliers and other business relationships to implement responsible business conduct policies'. ${ }^{176}$ It prescribes a cooperative approach to business relationships, including providing technical assistance to suppliers in implementing HRDD processes, and facilitating access to finance. ${ }^{177}$ Firms should engage meaningfully with stakeholders and seek the input of those affected by a firm's activities at critical junctures of HRDD, such as its design and the implementation of corrective plans. Firms should offer remedies to those harmed, including via operational-level grievance mechanisms that support early identification of adverse impacts and early remediation for social and environmental harm. ${ }^{178}$ HRDD, as prescribed by the UNGPs and implementing instruments, contains important other-regarding mechanisms for the incorporation of affected interests (of human rights holders as well as suppliers) in corporate decision making in respect of human rights. HRDD therefore offers the tools to 'proceduralize' and 'publicize' transnational corporations and contributes to aligning public and private goals. ${ }^{179}$

While HRDD generally has been received positively, criticism has addressed the UNGPs' lack of binding character, as reflected in the notion of 'moral responsibility'

\footnotetext{
171 UNGPs, n. 128 above, Principles 15 and 17.

172 Ibid., Commentary to UNGP 17.

173 Ibid., Principle 18.

174 OECD/FAO, OECD-FAO Guidance for Responsible Agricultural Supply Chains (OECD, 2016).

175 OECD, OECD Guidelines for Multinational Enterprises (OECD, 2011), p. 31.

176 OECD, OECD Due Diligence Guidance for Responsible Business Conduct (OECD, 2018), p. 24.

177 Ibid., p. 80.

178 UNGPs, n. 128 above, Principle 29.
}

179 E. Partiti, 'Trust in Global Governance: Ensuring Trustworthiness of Transnational Private Regulators (2020) 52(2) NYU Journal of International Law \& Politics, pp. 415-84, at $475 \mathrm{ff}$. 
over 'duty' and their trust in market forces to sanction human rights violations in the absence of public enforcement. ${ }^{180}$ HRDD has an ambivalent nature, as it is used both to define management processes tackling human rights risk, and as a standard of conduct to discharge the business obligation to respect. ${ }^{181}$ The HRDD framework is also afflicted by indeterminacy on crucial issues, such as which human rights are covered. This indeterminacy limits effectiveness, ${ }^{182}$ as corporations exploit open-ended definitions and procedures to strategically dilute their human rights responsibility, ${ }^{183}$ or approach it as a box-ticking exercise. ${ }^{184}$ Human rights impact assessment is frequently limited to human rights such as workspace health and safety, and rarely includes rights of Indigenous communities. ${ }^{185}$ Aspects that are missed in impact assessments will not be addressed by corporate HRDD. ${ }^{186}$

It was claimed in Section 4.1 that firms' management systems can serve public goals only where public interest considerations prevail over economic interests. Similarly, managing human rights risks by way of the UNGPs can be accomplished only by elevating respect for human rights to a company objective incorporated in risk management systems, and equating human rights impacts to vulnerabilities for the corporation itself. ${ }^{187}$ This can hardly occur through spontaneous acceptance by businesses. Making HRDD mandatory is essential in order to establish proper incentives and expectations. HRDD has been made mandatory in certain countries, albeit with varying stringency. The UK Modern Slavery Act requires companies simply to declare whether a due diligence system has been established, and provide a report on it. ${ }^{188}$ Voluntary reporting generates limited change in supply-chain practices compared with the imposition of corporate liability. ${ }^{189}$ Measures that impose liability in connection with supply-chain practices include a French law on the Duty of Vigilance, which

180 B. Santoso, “Just Business”: Is the Current Regulatory Framework an Adequate Solution to Human Rights Abuses by Transnational Corporations?' (2017) 18(3) German Law Journal, pp. 533-58, at 549.

181 J. Bonnitcha \& R. McCorquodale, 'The Concept of "Due Diligence" in the UN Guiding Principles on Business and Human Rights' (2017) 28(3) European Journal of International Law, pp. 899-919.

182 E. Partiti, 'Polycentricity and Polyphony in International Law: Interpreting the Corporate Responsibility to Respect Human Rights' (2021) 70(4) International and Comparative Law Quarterly, pp. 133-64.

183 Working Group on the Issue of Human Rights and Transnational Corporations and Other Business Enterprises, 'Report to the General Assembly on the Issue of Human Rights and Transnational Corporations and Other Business Enterprises', 16 July 2018, UN Doc. A/73/163, p. 8.

184 O. Martin-Ortega, 'Human Rights Risk in Global Supply Chains: Applying the UK Modern Slavery Act to the Public Sector' (2017) 8(4) Global Policy, pp. 512-21.

185 R. McCorquodale et al., 'Human Rights Due Diligence in Law and Practice: Good Practices and Challenges for Business Enterprises' (2017) 2(2) Business and Human Rights Journal, pp. 195-224, at 205-6.

186 S. Engle Merry, 'Measuring the World: Indicators, Human Rights and Global Governance' (2011) 52(S3) Current Anthropology, pp. S83-S95.

187 B. Fasterling, 'Human Rights Due Diligence as Risk Management: Social Risk Versus Human Rights Risk' (2017) 2(2) Business and Human Rights, pp. 225-47.

188 Modern Slavery Act 2015, c. 30, s. 54.

189 G. LeBaron \& A. Rühmkorf, 'Steering CSR through Home State Regulation: A Comparison of the Impact of the UK Bribery Act and Modern Slavery Act on Global Supply Chain Governance' (2017) 8(S3) Global Policy, pp. 15-28. 
also appraises the quality and effectiveness of the processes established, ${ }^{190}$ and a Dutch law on child labour. ${ }^{191}$ The development with the most impact will be the establishment of EU legislation on mandatory due diligence. Following a preliminary study ${ }^{192}$ the EU Commissioners for Justice and Consumers and for Trade committed to set out by 2021 a proposal for across-the-board due diligence, with possible sectoral guidance. ${ }^{193}$ The EU Conflict Minerals Regulation is the first EU example of a measure that makes HRDD mandatory in line with the UNGPs. ${ }^{194}$

\subsection{Leveraging the HRDD Framework}

Both HRDD and non-financial due diligence serve as ex ante modes of accountability where, for various reasons, ex post compensation is suboptimal. Using HRDD constructs in non-financial due diligence for deforestation, ecosystem conversion, and associated human rights violations mobilizes the procedural and conceptual dimensions offered by HRDD. Firstly, HRDD allocates responsibilities for conversion and human rights violations in value chains by outlining expected actions towards entities with which a firm has commercial relations and situations where remediation for harm is required. Where value chains stretch across jurisdictions, firms marketing FERCs downstream have the responsibility to ensure that the products they trade are not associated with certain risks with which they would be directly linked. They must take appropriate actions to leverage their suppliers and disengage with them if necessary. Vertically integrated firms may instead cause detrimental impacts and must thus immediately cease to generate such impacts and offer remediation.

Secondly, HRDD contributes to the granularity of non-financial due diligence processes by prescribing key steps in management-based regulation (policy planning, reporting, offering remedies) as well as including affected interests and providing compensation to those harmed. Such provisions are missing in the EUTR. Policy statements and planning are instrumental in clearly embedding public concerns in business operations and drawing the boundaries of expected conduct. Reporting generates accountability and empowers private monitoring. Including affected interests in decision making and offering compensation implement procedural obligations and responsibilities. If implemented with strong monitoring and enforcement systems - such as mandatory audits to verify the proper establishment and functioning of due diligence systems, ex post checks, private enforcement - and strengthened by a liability and sanctions regime, such a procedural dimension can operationalize public objectives in

${ }^{190}$ Loi n 2017-399 du 27 mars 2017 relative au devoir de vigilance des sociétés mères et des entreprises donneuses d'ordre.

191 Wet zorgplicht kinderarbeid, Stb. 2019, 401.

192 L. Smit et al., 'Study on Due Diligence Requirements through the Supply Chain', Jan. 2020, available at: https://op.europa.eu/en/publication-detail/-/publication/8ba0a8fd-4c83-11ea-b8b7-01aa75ed71a1.

193 Introductory Remarks by Commissioner Phil Hogan at OECD Global Forum on Responsible Business Conduct, 19 May 2020.

194 Regulation (EU) 2017/821 Laying down Supply Chain Due Diligence Obligations for Union Importers of Tin, Tantalum and Tungsten, Their Ores, and Gold Originating from Conflict-affected and High-risk Areas [2017] OJ L 130/1, Art. 3. 
supply-chain management. It constitutes the vehicle through which substantive standards of no-conversion and FPIC are implemented by companies.

Substantively, HRDD includes ensuring that corporate activities do not infringe or contribute to the infringement of Indigenous rights regardless of domestic law. ${ }^{195}$ This means that companies must not violate the substantive and procedural rights of such communities - encompassing participation in decision making, FPIC, access to justice and information, as laid down in International Labour Organization (ILO) Convention 169, the non-binding UN Declaration on the Rights of Indigenous Peoples (UNDRIP), and in customary international law. ${ }^{196}$ The UNGPs also require and outline firm-level grievance mechanisms to support the identification of adverse human rights impacts and provide remedies. ${ }^{197}$ Public intervention could still clarify the expected standard for land use and cultural identity of Indigenous communities, and the relevant procedural expectations. This could be done on the basis of the UNDRIP, which includes a comprehensive description of substantive and procedural Indigenous standards such as a right to the lands which they have traditionally owned or occupied, the provision of restoration to the status quo ante and compensation, access to justice and remedies, ${ }^{198}$ and a comprehensive treatment of FPIC. ${ }^{199}$

Public intervention should also refer to the relevant REDD+ Guidelines - a normative, policy and operational framework that applies to REDD+ activities $^{200}$ and outlines detailed FPIC criteria on the basis of the practice of human rights bodies and developments concerning the protection of traditional knowledge. ${ }^{201}$ Despite the REDD+ Guidelines, the application of FPIC remains challenging given the difficulties in understanding how FPIC is operationalized in different socio-political contexts. The terms of FPIC are also subjective and influenced by cultural interpretations and political interests, and its procedural nature may generate ambiguous results. ${ }^{202}$ To further flesh out relevant standards of FPIC in specific countries and contexts, engagement with partner countries and local stakeholders is indispensable. This could be based on the experience of FLEGT VPAs in defining timber legality. Such engagement would also

${ }^{195}$ UN Human Rights Council, 'Report of the Special Rapporteur on the Rights of Indigenous Peoples', 6 July 2012, UN Doc. A/HRC/21/47, para. 61.

196 B. Olmos Giupponi, 'Free, Prior and Informed Consent (FPIC) of Indigenous Peoples before Human Rights Courts and International Investment Tribunals: Two Sides of the Same Coin?' (2018) 25(4) International Journal on Minority and Group Rights, pp. 485-529.

${ }^{197}$ UNGPs, n. 128 above, Principles 30 and 31.

198 UNGA Res. 61/295, n. 114 above.

199 A. Savaresi, 'The Human Rights Dimension of REDD' (2012) 21(2) Review of European Community and International Environmental Law, pp. 102-13, at 107.

${ }^{200}$ UN-REDD, 'Guidelines on Free, Prior and Informed Consent', 13 Nov. 2013, p. 4, available at: https://www.unredd.net/documents/un-redd-partner-countries-181/templates-forms-and-guidance-89/ un-redd-fpic-guidelines-2648/8717-un-redd-fpic-guidelines-working-final-8717.html?path=un-reddpartner-countries-181/templates-forms-and-guidance-89/un-redd-fpic-guidelines-2648.

201 A. Savaresi, 'REDD+ and Human Rights: Addressing Synergies between International Regimes' (2013) 18(3) Ecology \& Society online articles, article 5, pp. 1-9, at 8, available at: http://www.ecologyandsociety.org/vol18/iss3/art5.

202 D. Szablowski, 'Operationalizing Free, Prior, and Informed Consent in the Extractive Industry Sector? Examining the Challenges of a Negotiated Model of Justice' (2010) 30(1-2) Canadian Journal of Development Studies, pp. 111-30. 
make it possible to leverage existing human rights commitments and obligations of producing countries.

In practice, corporations would have to assess whether claims of Indigenous land use exist in the area of origin of products, regardless of whether national laws permit such claims. If so, they must obtain evidence of effective FPIC. If they do not then, depending on their association with human rights impacts (namely, whether they 'caused or contributed' or they are 'directly linked'), compensation must be provided and firms must disengage from suppliers. Any decision concerning disengagement should be rights-based, and appraise whether it would not worsen the situation for rights holders such as Indigenous communities. ${ }^{203}$

Moreover, HRDD entails a far-reaching environmental dimension. Human rights impacts can stem from environmental harm, which is expressly considered to be a potentially severe human rights impact that corporations must prioritize in HRDD. ${ }^{204}$ Deforestation and ecosystem conversion are key drivers of climate change, which undermines the realization of a wide set of internationally recognized human rights. ${ }^{205}$ Regardless of climate change implications, agricultural operations have profound ramifications for food, water, health, and the livelihoods of affected communities. It has been argued that all actors that contribute to deforestation - including corporations - could be considered as having a moral obligation to be part of the solution. ${ }^{206}$ The French law on the Duty of Vigilance expressly covers environmental damage or health risks resulting directly or indirectly from corporate operations and firms under corporate control, ${ }^{207}$ potentially disassociating these from human rights violations. The first legal action brought under the new law also concerned environmental impacts. $^{208}$

Including deforestation and ecosystem conversion in the environmental components of HRDD is possible. The content of due diligence for states and non-state actors is dynamic. In several areas of international law due diligence grew steadily to include higher principles and responsibilities. ${ }^{209}$ While the international regime for deforestation is notoriously weak, support for stopping conversion regardless of legality has grown steadily and is reflected in a rising number of public instruments. International standards for responsible business conduct include both social and environmental impacts. The OECD/FAO Guidance on Responsible Agriculture Supply

\footnotetext{
${ }^{203}$ UN OHCHR, n. 164 above, pp. 50-1.

${ }^{204}$ Ibid., p. 8.

205 UN Human Rights Council Res. 7/23 'Human Rights and Climate Change', 28 Mar. 2008, UN Doc. AIHRC/7f78; M. Limon, 'Human Rights and Climate Change: Constructing a Case for Political Action' (2009) 33(2) Harvard Environmental Law Review, pp. 439-76.

${ }^{206}$ F. Seymour, 'Forests, Climate Change and Human Rights: Managing Risks and Trade-offs', in S. Humphreys (ed.), Human Rights and Climate Change (Cambridge University Press, 2010), p. 225.

${ }^{207}$ Loi n 2017-399, n. 190 above, Art. L.225-102-4.

208 Business \& Human Rights Resource Centre, 'Total Sued under France's New Duty of Vigilance Law', 23 Oct. 2019, available at: https://www.business-humanrights.org/en/latest-news/total-sued-under-frances-new-duty-of-vigilance-law.

209 J. Aguon \& J. Hunder, 'Second Wave Due Diligence: The Case for Incorporating Free, Prior and Informed Consent into the Deep Sea Mining Regulatory Regime' (2018) 38(3) Stanford Environmental Law Journal, pp. 3-55, at 8 .
} 
Chains includes deforestation, ecosystem conversion and degradation, and other environmental impacts as part of the expected social and environmental risks assessment. ${ }^{210}$ SDG 15 includes targets with the aim of arresting deforestation and ecosystem destruction and degradation. The Aichi Biodiversity Targets under the Convention on Biological Diversity ${ }^{211}$ similarly aim to reduce natural habitat loss and degradation. ${ }^{212}$ Among the most high-profile multi-stakeholder pledges - involving 200 national and regional governments, companies, NGOs and Indigenous communities - the UN New York Declaration on Forests aims to halve the rate of natural forest loss by 2020 , and end natural forest loss by 2030, by establishing a clear link between conversion and human rights violations. ${ }^{213}$

Regardless of whether it is possible to extend HRDD to deforestation and conversion within the framework of the UNGPs, there is nothing to prevent public authorities at the national or regional level from implementing the UNGPs and HRDD in a stricter manner. Public authorities can discipline forest and ecosystem conversion via HRDD without drawing a connection between deforestation and human rights. Expanding the substantive scope of HRDD with non-financial due diligence legislation may 'simply' generate liability under the measure in question or under national laws on responsibility for damage or failure to exercise due diligence. ${ }^{214}$ Private frameworks such as the AFI already mobilize HRDD constructs to elucidate expected corporate action on land-use conversion, thereby grounding normatively desirable practices in the UNGPs. ${ }^{215}$ Private standard setters have embraced HRDD, and use its normative weight instrumentally to justify and give meaning to corporate practices that otherwise would be complex to define and support.

EU intervention similarly should prescribe the details of due diligence systems in line with HRDD. Due diligence systems must empower economic operators with appropriate information about whether FERCs are associated with forest and ecosystem risk, on the basis of which they can decide whether to market in the EU. Businesses marketing in the EU must obtain information about the area (or areas) of harvest and pasture, the present status of the area with reference to definitions of natural forests and ecosystems, the status of the area at an indicated cut-off date, the legal status of land and evidence of FPIC. Operators must also acquire information on the entire supply chain, especially on the risks of contamination with products of unknown origin, or originating from forest and ecosystem conversion and degradation, at critical bottlenecks such as collection points, mills, storage and processing facilities. Due diligence systems will thus ensure full traceability while allowing firms continuously to assess forest and ecosystem risk.

\footnotetext{
210 OECD/FAO, n. 174 above, pp. 65-6.

211 Rio de Janeiro (Brazil), 5 June 1992, in force 29 Dec. 1993, available at: https://www.cbd.int.

212 Aichi Biodiversity Targets, available at: https://www.cbd.int/sp/targets.

213 N. 15 above.

214 N. Bueno \& C. Bright, 'Implementing Human Rights Due Diligence through Corporate Civil Liability' (2020) 69(4) International and Comparative Law Quarterly, pp. 789-818.

215 AFI, 'Operational Guidance on Supply Chain Management', 2019, p. 29; AFI, 'Operational Guidance on Remediation and Access to Remedy', 2019, p. 10.
} 
Risk would be enhanced where FERCs originate from countries or areas affected by deforestation, conversion and degradation, where violations of land-related human rights (including FPIC) are reported, or where firms are unable to guarantee that the commodities they supply are compliant. Where risk assessment reveals a nonnegligible risk, a firm must adopt mitigation measures and require additional information, verification by means of independent audit, and appropriate actions from relevant suppliers. Risk mitigation also includes initiatives with other upstream suppliers, such as chain of custody measures. It includes the use of economic and non-economic leverage towards non-compliant suppliers, ultimately disengaging from those that cannot ensure negligible risks. Operators must report to competent authorities and to the general public.

Meaningful stakeholder engagement with suppliers and competitors throughout due diligence processes is also required. Participating in integrated landscape-management initiatives is a promising option to generate economic and non-economic synergies, to ensure that affected interests are taken into account, and to create positive impact also for products not destined for EU markets. ${ }^{216}$ Rights-based approaches to conservation deriving from the REDD+ experience are also indirectly included in HRDD. HRDD requires embedding human rights considerations at all stages of corporate activities, especially where disengagement with suppliers (in particular, smallholders) on environmental grounds may generate human rights impacts. Meaningful engagement, also with Indigenous communities, must thus determine whether disengaging from a supplier would worsen human rights impacts. Non-financial due diligence must also offer operational-level grievance mechanisms in line with the UNGPs. Firms must offer remediation for impacts on Indigenous communities and restoration for environmental impacts. ${ }^{217}$ Finally, guidance must be established to facilitate rather than exclude smallholders to accede to value chains. ${ }^{218}$

\subsection{Indirect Enrolment and Meta-Regulation of Private Standards}

Setting detailed procedural requirements for supply-chain management as well as precise no-conversion criteria has the indirect effect of scaling up private standards. As voluntary standards generally also help firms to comply with mandatory requirements, the imposition of non-financial due diligence requirements aligned to HRDD will be reflected in private standards, which will adjust accordingly to enhance their uptake by firms. Adjustments are not limited to the requirements for management processes, but may also include the introduction or revision of grievance mechanisms and other accountability provisions offered by private standards. To achieve this, it is not necessary to identify specific schemes to be used, as happened under the EU Renewable

\footnotetext{
216 N. Estrada-Carmona et al., 'Integrated Landscape Management for Agriculture, Rural Livelihoods, and Ecosystem Conservation: An Assessment of Experience from Latin America and the Caribbean' (2014) 129 Landscape and Urban Planning, pp. 1-11.

${ }^{217}$ AFI, n. 141 above.

218 AFI, 'Operational Guidance on Smallholder Inclusion in Ethical Supply Chains', 2019.
} 
Energy Directive. ${ }^{219}$ It is sufficient to allow firms to use certification against a private standard, which conforms with the legally binding criteria, to serve as non-dispositive evidence of low risk of impact on forests, ecosystems, and people. The most profound effects concern the designation and definition of protected forests and ecosystems, and cut-off dates.

Definitional work by EU authorities would include the definition of FERCs and products covered on the basis of their association with conversion, degradation, and human rights impact. The relevant measure would then define deforestation, conversion of ecosystems, as well as natural forests and natural ecosystems, with appropriate tools for their identification. Definitions in line with those of the AFI can be used to protect all natural ecosystems. A natural forest is a 'forest that is a natural ecosystem' and 'possesses many or most of the characteristics of a forest native to the given site, including species composition, structure, and ecological function'. ${ }^{220}$ Under the AFI, natural forests are understood broadly to include primary forests, regenerated (second-growth) forests, managed natural forests, and partially degraded forests not yet converted to another land use. ${ }^{221}$ A similar definition applies mutatis mutandis for natural ecosystems. $^{222}$ The European Commission must subsequently identify methodologies, and provide further guidance to operators in identifying natural forests and ecosystems. The Commission should also be empowered to manage and update a list of natural ecosystems covered. As a minimum, ecosystems protected under other EU measures addressing the sustainability of commodities should be included. These include HCV ecosystems, some of which are identified under the Renewable Energy Directive, including HCS land. The measure could also include a prohibition on market commodities and products originating from degraded forests and ecosystems. In such a case the Commission also would have to provide guidance on the degree of changes that would amount to degradation as a result of human activity.

A cut-off date must also be determined to establish a point in time before which economic entities are not liable for conversion and degradation. Products and commodities originating from land that has been converted or degraded after the cut-off date would not qualify. Firms must thus acquire information to demonstrate that the area of origin of covered goods did not possess the status of natural forest or natural ecosystem at the cut-off date. Generally, a non-retroactive identification of deforested areas, say, from the entry into force of the measure is unlikely to be effective as it may generate a 'deforestation rush'. Among possible retroactive options, 2005 is the year against which EU emissions reduction targets are set for the Emission Trading Scheme (ETS) and non-ETS sectors, and 2008 is the cut-off year adopted for land-use change in the production of renewable energy, and is also incorporated in several private regimes. ${ }^{223}$

219 Directive (EU) 2018/2001 on the Promotion of the Use of Energy from Renewable Sources [2018] OJ L 328/82, Art. 30(4).

${ }^{220}$ Accountability Framework, 'Terms and Definitions', June 2019, p. 16, available at: https://accountabilityframework.org/wp-content/uploads/2019/07/Definitions.pdf.

${ }^{221}$ Ibid.

222 Ibid.

${ }^{223}$ Such as RSPO for plantations. 


\section{CONCLUSION}

Public authorities retain the tools to coordinate various regimes and act as the complementary locus of rulemaking authority to scale up private norms. This article has analyzed how non-financial due diligence in line with the UNGPs can be the keystone affecting private regulation in various guises in a nascent but conflicted TLO governing deforestation, ecosystem conversion and degradation, and human rights violations associated with global demand for FERCs. An EU measure that disciplines market access on the basis of no-conversion criteria would enrol supply chain management systems in the identification of economic operators responsible for deforestation with a view to excluding them from the market and transforming value chains. While it is uncontroversial that HRDD responsibilities include rights of Indigenous communities, the HRDD framework can be extended to forest and ecosystem conversion. HRDD is particularly valuable as it allocates responsibilities for harm caused by or directly linked to firms. At the same time, it provides the boundaries of expected corporate conduct while offering accountability, participation, and remediation mechanisms. Providing detailed obligations concerning non-financial due diligence, clarifying applicable standards for Indigenous rights, and defining relevant ecosystems would also have an impact on private schemes and contribute to their alignment with public goals.

The resulting TLO would then still mainly unfold through corporate management systems but, under public enforcement occurring where products are placed on the EU market and exposed to a regime of sanctions, these tools would be positioned to operate under the appropriate incentives, moving away from operational risks, and would be proceduralized to operate in the public interest. At the same time, public authority could allocate regulatory competences to actors who are currently better placed to affect economic and trade-related drivers of forest and ecosystem conversion and violations of Indigenous community rights. This allocation also indirectly enables private standard setters to exercise implementing functions supporting firms' compliance with their non-financial due diligence obligations.

These EU-initiated interactions enrolling firms and private standards via the establishment of non-financial due diligence would contribute to establishing a substantively coherent TLO - albeit a partial one, applying to the extent that FERCs are marketed in the EU. $\mathrm{EU}$ action, and unilateral action in general, cannot directly address value chains disconnected from the EU market. However, as management practices are often implemented across firms in the entirety of their operations in the light of technical and economic nondivisibility of production, ${ }^{224}$ no-conversion principles could also extend to value chains destined for non-EU markets. This would be the case particularly if key value chain nodes, such as mills and processing facilities, decide to run all their operations in line with EU criteria, and if firms engage upstream in landscape-management initiatives supporting the implementation of zero-deforestation criteria, thereby contributing to the further extension of global regulatory effects, even in the absence of a connection with the EU market.

224 A. Bradford, The Brussels Effect: How the European Union Rules the World (Oxford University Press, 2020), pp. 57-9. 